\title{
PHASES OF HUMANISTIC THEORY: ANALYSIS OF APPLICABILITY IN RESEARCH
}

\author{
Ana Luiza Paula de Aguiar Lélis', Lorita Marlena Freitag Pagliuca², Maria Vera Lúcia Moreira Leitão \\ Cardoso $^{3}$
}

${ }^{1}$ Ph.D. candidate in Nursing, Graduate Program at Universidade Federal do Ceará (UFC). Fortaleza, Ceará, Brazil. E-mail: aninhanurse@hotmail.com

${ }^{2}$ Ph.D. in Nursing. Full Professor, Nursing Department at UFC. Fortaleza, Ceará, Brazil. E-mail: pagliuca@ufc.br

${ }^{3}$ Ph.D. in Nursing. Full Professor, Nursing Department at UFC. Fortaleza, Ceará, Brazil. E-mail: cardoso@ufc.br

\begin{abstract}
The goal was to analyze the applicability of the phases of Humanistic Theory in research, according to a Theory Analysis Model. Critical nursing theory analysis study with emphasis on applicability. A search was carried out in April and May 2013 in the databases SCOPUS, Cumulative Index of Nursing and Allied Health Literature and in the publications available in the Virtual Health Library. The following descriptors were used: "Teoria de Enfermagem" and "Pesquisa em Enfermagem" and Nursing Theory and Nursing Research, in publications from 2002 until May 2013. Seven papers were selected, five of which displayed all phases in their development, evidencing the applicability of Humanistic Theory for methodological support in nursing research.
\end{abstract}

DESCRIPTORS: Nursing theory. Nursing research. Nursing.

\section{FASES DA TEORIA HUMANÍSTICA: ANÁLISE DA APLICABILIDADE EM PESQUISA}

RESUMO: Objetivou-se analisar a aplicabilidade das fases da Teoria Humanística em pesquisas, segundo um Modelo de Análise de Teoria. Estudo de análise crítica de teoria de enfermagem com ênfase na aplicabilidade. Realizou-se a busca, em abril e maio de 2013, nas bases de dados SCOPUS, Cumulative Index of Nursing and Allied Health Literature e nas disponíveis na Biblioteca Virtual em Saúde. Foram utilizados os descritores: "Teoria de Enfermagem" e "Pesquisa em Enfermagem" e Nursing Theory e Nursing Research, em publicações de 2002 até maio de 2013. Sete artigos foram selecionados, dos quais cinco apresentaram todas as etapas em seu desenvolvimento, evidenciando a aplicabilidade da Teoria Humanística como suporte metodológico nas pesquisas de enfermagem.

DESCRITORES: Teoria de enfermagem. Pesquisa em enfermagem. Enfermagem.

\section{FASES DE LA TEORÍA HUMANÍSTICA: ANÁLISIS DE LA APLICABILIDAD EN INVESTIGACIÓN}

RESUMEN: El objetivo fue analizar la aplicabilidad de las fases de la Teoría Humanística en investigaciones, según un Modelo de Análisis de Teoría. Estudio de análisis crítica de teoría de enfermería con énfasis en la aplicabilidad. Fue efectuada una búsqueda, en abril y mayo de 2013, en las bases de datos SCOPUS, Cumulative Index of Nursing and Allied Health Literature y en las disponibles en la Biblioteca Virtual de Salud. Fueron utilizados los descriptores: "Teoria de Enfermagem" y "Pesquisa em Enfermagem" y Nursing Theory y Nursing Research, en publicaciones del 2002 hasta mayo de 2013. Siete artículos fueron seleccionados, de los cuales cinco revelaron todas las etapas en su desarrollo, evidenciando la aplicabilidad de la Teoría Humanística como soporte metodológico en las investigaciones de enfermería.

DESCRIPTORES: Teoría de enfermería. Investigación en enfermería. Enfermería. 


\section{INTRODUCTION}

Theory in research consists of a set of concepts and propositions that constitute a logically interrelated system, providing a mechanism for the logical deduction of new declarations, based on the original propositions. ${ }^{1}$ In nursing, theory is defined as the conceptualization of aspects of the nursing reality, with a view to describing and explaining the relations between the phenomena, previewing consequences or describing the nursing care. ${ }^{2}$

Nurses have been developing and applying theory in practice and research, with a view to refining and expanding the scientific knowledge and contributing to studies that reflect the relevance and valuation of nursing as a scientific discipline in the clinical care, professional and academic spheres. ${ }^{3}$

Developing research with theoretical support offers support to extend, examine, develop or validate a theory; its findings imply a higher level of understanding and abstraction, contributing more significantly to enhance the understanding of the Nursing discipline. ${ }^{4}$

Among the theories that are clearly relevant for nursing, the Humanistic Theory stands out, whose premises can be applied to guide clinical practice and which offers a method to drive professional practice. ${ }^{5-6}$ It is not only congruent with the nature of nursing but also addresses aspects of the human sciences. ${ }^{2}$

The method of the Humanistic Theory is called Phenomenological Nursing, based on existentialism and phenomenology, and consists of five structured phases, in accordance with the scientific method: nurse preparation for coming to know; nurse's intuitive knowledge about the other; nurse's scientific knowledge about the other; nurse's supplementary synthesis about the realities she/he knows; and, finally, nurse inner succession from many to a paradoxal one. . $^{5-6}$

It is highlighted that the phases of the Humanistic Theory allow the nurses to apply them in care as well as in research. In daily practice, the professionals can choose to use them for the development of studies, as well as the Nursing Process, to drive nursing practice.

In the daily reality of nursing, theory and practice do not exist separately; on the opposite, they are intertwined in an articulated manner with their praxis, in response to the knowledge and need of the care-being. ${ }^{7}$
In the context of nursing research, although the five phases of the Humanistic Theory have been described and presented in publications, the diversity of their use for methodological support hampers the appropriate understanding of their applicability.

That aroused the interest in discovering how nurses are applying the five phases of the Humanistic Theory in research in the different scenarios of nursing praxis. As far as known, when one uses a theory for clinical practice or to drive research, it should be critically examined so as to appropriately understand its nature, considering that, without a careful examination, decisions for care, guided by the theory, will be less effective and research results based on the theory will probably be flawed. ${ }^{4}$

Based on these assertions, this study was focused on analyzing the applicability of the phases of the Humanistic Theory in research, based on a Theory Analysis Model.

\section{HUMANISTIC THEORY AND PHENOME- NOLOGICAL NURSING}

Humanistic Nursing structurally consists of three concepts that support the base of nursing: dialogue, community and Phenomenological Nursing. ${ }^{5-6}$

The dialogue experienced refers to a particular form of intersubjective relation, by sharing experiences among the individuals, and which involves some essential elements for the establishment of a complete dialogue: meeting, relation, presence, call and response. This relation is understood through three dimensions: the I-YOU relationship (subject-subject), the I-IT relationship (subject-object) and the We relationship (community between two or more people). ${ }^{5-6}$

Community is developed when two or more people discover the meaning of their existence by sharing and establishing a relation with one another. ${ }^{8}$ The people involved present similar ideas and thoughts, in a communion of experiences, about a certain phenomenon, even if these are culturally different people who live in distinct places. ${ }^{9}$

When considering the nurses' experiences with the dialogue relations, Phenomenological Nursing is a method of Humanistic Nursing practice, as an instrument to describe the professional clinical situation of nursing, experienced in the subjective-objective world, between subjectiveobjective beings. ${ }^{5-6}$ 
Phenomenological Nursing is divided in five phases. In the first phase, nurse preparation for coming to know, introspective and scientifically, to start the investigation of the phenomenon. They stand open and are available to other experiences and perceptions, free themselves from prejudices and judgments and, at the same time, acknowledge their own worldview. Moreover, they attempt to read on and study the nature of man and the object that is to be studied. ${ }^{5-6}$

In the second phase, nurse's intuitive knowledge about the other. That is the moment of the dialogical encounter, of the true I-YOU relationship, when two beings are present: one person as the I and the other as the YOU, in a transactional relation, ${ }^{10}$ in which the nurses attempt to get to know the other persona view on the study phenomenon. ${ }^{5-6}$

In the third phase, nurse's scientific knowledge about the other, establishing the subjectobject relationship (I-IT). That is a moment of reflection and analysis on the experience lived (in the past), and is aimed at permitting the analysis, classification, comparison and categorization of the study object. ${ }^{5-6}$

In the fourth phase, nurse's supplementary synthesis about the realities she/ he knows. ${ }^{5-6}$ In the fifth and final phase, nurse inner succession from many to a paradoxal one. Based on ideas extracted from each situation, a unit or a set is conquered, constituting a conception that represents the research object. ${ }^{5-6}$

\section{METHOD}

This study presents a critical nursing theory analysis, emphasizing the applicability of the methodological phases of the Humanistic Theory referenced in studies published in nursing, with support from the use of Chinn and Kramer's Theory Analysis Model. The selected model comprises a description and critical analysis of nursing theory, and can be used as a whole or in parts. The critical analysis contains the following components: clarity, simplicity, generality, accessibility, importance and applicability. The applicability of the theory can be analyzed in teaching, in research or in practice. ${ }^{4}$ In this study, the analysis of the applicability of the theory in research was chosen.

To develop the critical analysis from this focus, the following central question was elaborated: is the Humanistic Theory applicable in research? To answer the central question, the Theory Analysis Model ${ }^{4}$ presents six questions, two of which are adopted in the study: does there exist evidence on the application of the phases of the Humanistic Theory in research? How have these phases been applied in nursing research? The answers through these questions were obtained through information taken from studies that were selected by means of a search in the relevant databases for the dissemination of nursing research.

For the bibliographic survey, a search was undertaken in April and May 2013 in the databases SCOPUS, Cumulative Index of Nursing and Allied Health Literature (CINAHL) and in the bases available through the Virtual Health Library (BVS), including: Latin-American and Caribbean Health Sciences Literature (LILACS), Índice Bibliográfico Español de Ciencias de la Salud (IBECS), International Literature in Health Sciences (MEDLINE), Cochrane Library, Scientific Electronic Library Online (SciELO), Library Collection of the Pan American Health Organization (PAHO) and World Health Organization Library Information System (WHOLIS). To identify the studies, the descriptors Teoria de Enfermagem and Pesquisa em Enfermagem were used, included in the Health Sciences Descriptors (DECS); for the search in BVS and the other databases, "Nursing Theory" and "Nursing Research" were used, included in the Medical Subject Headings (MESH). The same sequence of these descriptors was followed for the searches in the three databases chosen, setting the period between 2002 and May 2013 as the limit for the publications.

The following inclusion criteria were defined: studies electronically available in the selected databases, in Portuguese, English and Spanish, which applied the phases of the Humanistic Theory. The exclusion criteria were: editorials, letters to the editor, reflections, experience reports and repeated publications.

In the selection process of the articles, initially, 532 papers were identified in CINAHL, 2,324 in SCOPUS and 1,567 in BVS; after reading the titles and abstract and removing repeated studies and studies whose methods/methodology section did not describe the applicability of the Humanistic Theory, seven papers remained for analysis. To preselect the articles, the titles were read, followed by the resumo or abstract. Then, the studies were fully analyzed using the research instrument. The critical analysis was developed by 
characterizing and synthetizing the description of the phases of the Humanistic Theory, applied in the selected articles, presented in figures and discussed descriptively based on relevant literature on the theme.

To collect the information from the selected articles, focused on the analysis questions, an instrument was elaborated with the following items: title, year of publication, authors, study design, study scenario, methodological phases and description of the application of each phase.

\section{RESULTS}

To answer the analysis questions, two figures were organized. Figure 1 contains the methodological information and, in figure 2, the applicability of the phases of the Humanistic Theory is described.

Figure 1 - Distribution of selected studies according to methodological aspects

\begin{tabular}{|c|c|c|c|c|c|c|}
\hline Title & $\begin{array}{c}\text { Journal } \\
\text { Year }\end{array}$ & Authors & Study design & Population & Scenario & Phases \\
\hline $\begin{array}{l}\text { O recém-nascido sob fo- } \\
\text { toterapia: a percepção da } \\
\text { mãe } \mathrm{e}^{11}\end{array}$ & $\begin{array}{l}\text { Rev Latino- } \\
\text { Am Enferm } \\
2004 \\
\end{array}$ & $\begin{array}{l}\text { Campos; } \\
\text { Cardoso }\end{array}$ & Qualitative & $\begin{array}{l}\text { Mothers of } \\
\text { infants in pho- } \\
\text { totherapy }\end{array}$ & $\begin{array}{l}\text { Neonatal ser- } \\
\text { vice }\end{array}$ & 5 \\
\hline $\begin{array}{l}\text { O diálogo vivido entre en- } \\
\text { fermeira e mãe de crianças } \\
\text { com câncer }^{12}\end{array}$ & $\begin{array}{l}\text { Rev Eletr } \\
\text { Enferm } \\
2006 \\
\end{array}$ & $\begin{array}{l}\text { Oliveira; } \\
\text { Costa; Nó- } \\
\text { brega }\end{array}$ & Qualitative & $\begin{array}{l}\text { Mothers of } \\
\text { children with } \\
\text { cancer }\end{array}$ & $\begin{array}{l}\text { Pediatric hospi- } \\
\text { tal service }\end{array}$ & 5 \\
\hline $\begin{array}{l}\text { Cuidado à família de crian- } \\
\text { ças em situação de abuso } \\
\text { sexual baseado na teoria } \\
\text { humanística }^{13}\end{array}$ & $\begin{array}{l}\text { Online Braz } \\
\text { J Nurs } \\
2007\end{array}$ & $\begin{array}{l}\text { Silva; } \\
\text { Galvão; } \\
\text { Araújo; } \\
\text { Cardoso }\end{array}$ & Qualitative & $\begin{array}{l}\text { Caregivers of } \\
\text { children in } \\
\text { sexual abuse } \\
\text { situations } \\
\end{array}$ & $\mathrm{NGO}$ & 5 \\
\hline $\begin{array}{l}\text { Existir de crianças com } \\
\text { aids em casa de apoio: } \\
\text { compreensões à luz da en- } \\
\text { fermagem humanística }^{14}\end{array}$ & $\begin{array}{l}\text { Rev Gaúcha } \\
\text { Enferm } \\
2008\end{array}$ & $\begin{array}{c}\text { Medeiros; } \\
\text { Mota }\end{array}$ & Qualitative & $\begin{array}{l}\text { Children with } \\
\text { HIV }\end{array}$ & $\begin{array}{l}\text { Support House } \\
\text { for children } \\
\text { with HIV/aids }\end{array}$ & 5 \\
\hline $\begin{array}{l}\text { A experiência existencial } \\
\text { de mães de crianças hos- } \\
\text { pitalizadas em Unidade de } \\
\text { Terapia Intensiva Pediátri- } \\
\text { ca }^{15}\end{array}$ & $\begin{array}{c}\text { Rev Esc } \\
\text { Enferm USP } \\
2009\end{array}$ & $\begin{array}{l}\text { Morais; } \\
\text { Costa }\end{array}$ & Qualitative & $\begin{array}{l}\text { Mothers of chil- } \\
\text { dren hospital- } \\
\text { ized at PICU }\end{array}$ & $\begin{array}{l}\text { Pediatric Inten- } \\
\text { sive Care Unit }\end{array}$ & 5 \\
\hline $\begin{array}{l}\text { O significado do transplan- } \\
\text { te de fígado para o paciente } \\
\text { em lista de espera: aborda- } \\
\text { gem fenomenológica }{ }^{16}\end{array}$ & $\begin{array}{l}\text { Rev Cuba } \\
\text { Enferm } \\
2012\end{array}$ & $\begin{array}{l}\text { Aguiar; } \\
\text { Braga }\end{array}$ & Qualitative & $\begin{array}{l}\text { Adults with ir- } \\
\text { reversible liver } \\
\text { diseases }\end{array}$ & $\begin{array}{l}\text { Outpatient } \\
\text { clinic of a Bra- } \\
\text { zilian referral } \\
\text { institution for } \\
\text { liver transplan- } \\
\text { tations in the } \\
\text { State of Ceará }\end{array}$ & 4 \\
\hline $\begin{array}{l}\text { O processo de parir assis- } \\
\text { tido pela enfermeira ob- } \\
\text { stétrica no contexto hospi- } \\
\text { talar: significados para as } \\
\text { parturientes }^{17}\end{array}$ & $\begin{array}{l}\text { Esc Anna } \\
\text { Nery } \\
2012\end{array}$ & $\begin{array}{l}\text { Caus; San- } \\
\text { tos; Nassif; } \\
\text { Monticelli }\end{array}$ & Qualitative & $\begin{array}{l}\text { Parturient } \\
\text { women }\end{array}$ & $\begin{array}{l}\text { Obstetric sector } \\
\text { of a public ma- } \\
\text { ternity hospital } \\
\text { in the State of } \\
\text { Santa Catarina }\end{array}$ & 3 \\
\hline
\end{tabular}

Five studies indicated the application of the Humanistic Theory in the title, as the theoreticalmethodological framework, or presented vocabulary relevant to the phenomenological and existential context characteristic of that theory. In total, seven studies were published between 2004 and 2012 in Brazilian journals, in Portuguese, one of which was also found in the English version in an international database.
Qualitative studies were predominant, which suggests the applicability of the phases of the Humanistic Theory in this kind of studies. The population consisted of mothers in two studies: mothers of children and a mother of a newborn; in the remainder, the subjects were caregivers, children, male and female adults and parturient women. The inpatient scenario appeared in four studies, the pediatric context 
in two, the neonatal and obstetric in one; two studies were undertaken in a Non-Governmental Organization (NGO) in Fortaleza-CE and a Support House in Rio Grande do Sul; and one an outpatient clinic of a Referral Institution in Liver Transplantations. These indications remit to the fact that pediatric and neonatal nursing are the areas that most develop research using the Humanistic Theory.

Among the seven studies, five applied the five phases of the Humanistic Theory, which were described in detail in the method or methodology section and presented in the results of the selected studies.

Figure 2 - Nursing research and the description of the applicability of the phases of the Humanistic Theory

\begin{tabular}{|c|c|c|c|c|c|}
\hline \multirow[b]{2}{*}{ Studies } & \multicolumn{5}{|c|}{ Phases of the Humanistic Theory } \\
\hline & \begin{tabular}{|c|} 
Nurse prepara- \\
tion for coming to \\
know
\end{tabular} & $\begin{array}{c}\text { Nurse's intuitive } \\
\text { knowledge about } \\
\text { the other }\end{array}$ & $\begin{array}{c}\text { Nurse's scientific } \\
\text { knowledge about } \\
\text { the other }\end{array}$ & $\begin{array}{l}\text { Nurse's supple- } \\
\text { mentary syn- } \\
\text { thesis about the } \\
\text { realities she/he } \\
\text { knows }\end{array}$ & $\begin{array}{l}\text { Nurse inner } \\
\text { succession } \\
\text { from many to a } \\
\text { paradoxal one }\end{array}$ \\
\hline $\begin{array}{l}\text { O recém-nascido } \\
\text { sob fototerapia: } \\
\text { a percepção da } \\
\text { mãe }{ }^{11}\end{array}$ & $\begin{array}{l}\text { Introspection; } \\
\text { self-knowledge; } \\
\text { literary readings; } \\
\text { deepening of the } \\
\text { theory. }\end{array}$ & $\begin{array}{l}\text { Informal conversa- } \\
\text { tions; observation } \\
\text { of mother and } \\
\text { child relationship. }\end{array}$ & $\begin{array}{l}\text { Listening, tran- } \\
\text { scription and } \\
\text { analysis of state- } \\
\text { ments. }\end{array}$ & \begin{tabular}{|c|} 
Analysis, inter- \\
pretation and \\
synthesis of state- \\
ments; construc- \\
tion of thematic \\
units and catego- \\
ries.
\end{tabular} & $\begin{array}{l}\text { Concept about } \\
\text { the phenom- } \\
\text { enon. }\end{array}$ \\
\hline $\begin{array}{c}\text { Diálogo vivo } \\
\text { entre enfermeira e } \\
\text { mães de crianças } \\
\text { com câncer }{ }^{2}\end{array}$ & $\begin{array}{l}\text { Self-knowledge; } \\
\text { reflections; read- } \\
\text { ing of books, } \\
\text { dissertations and } \\
\text { papers; watching } \\
\text { movies; participa- } \\
\text { tion in congresses. }\end{array}$ & $\begin{array}{l}\text { Getting to know } \\
\text { the mothers' } \\
\text { reality; listening to } \\
\text { narratives; verbal } \\
\text { and non-verbal } \\
\text { communication. }\end{array}$ & $\begin{array}{c}\text { Analysis of the } \\
\text { statements. }\end{array}$ & $\begin{array}{l}\text { Construction of } \\
\text { the categories. }\end{array}$ & $\begin{array}{l}\text { Reflection on } \\
\text { the phenom- } \\
\text { enon. }\end{array}$ \\
\hline $\begin{array}{c}\text { Cuidado à família } \\
\text { de crianças em } \\
\text { situação de abuso } \\
\text { sexual baseado na } \\
\text { teoria humanísti- } \\
\text { ca }^{13} \\
\end{array}$ & \begin{tabular}{|c|} 
Contact with \\
NGO; support for \\
the theory.
\end{tabular} & $\begin{array}{l}\text { Presence; approxi- } \\
\text { mation of subjects; } \\
\text { call and response. }\end{array}$ & $\begin{array}{l}\text { Distancing from } \\
\text { object; moment of } \\
\text { reflection, analy- } \\
\text { sis, comparison } \\
\text { and visualization } \\
\text { of contrasts. } \\
\end{array}$ & $\begin{array}{c}\text { Comparison } \\
\text { of statements; } \\
\text { perception of } \\
\text { contrasts in the } \\
\text { subjects' state- } \\
\text { ments. }\end{array}$ & $\begin{array}{l}\text { Reflection on } \\
\text { the phenom- } \\
\text { enon. }\end{array}$ \\
\hline $\begin{array}{c}\text { Existir de crianças } \\
\text { com aids em casa } \\
\text { de apoio: com- } \\
\text { preensão à luz } \\
\text { da enfermagem } \\
\text { humanística }^{14}\end{array}$ & $\begin{array}{c}\text { The children's life } \\
\text { history; readings } \\
\text { of the theory. }\end{array}$ & $\begin{array}{c}\text { Definition of study } \\
\text { area, participants } \\
\text { and data collec- } \\
\text { tion; data collec- } \\
\text { tion - interview; } \\
\text { observation and } \\
\text { drawing. } \\
\end{array}$ & $\begin{array}{c}\text { Separation of } \\
\text { what was ex- } \\
\text { perienced; data } \\
\text { interpretation and } \\
\text { classification }\end{array}$ & $\begin{array}{l}\text { Reflection on the } \\
\text { experience of each } \\
\text { child; presenta- } \\
\text { tion of the catego- } \\
\text { ries. }\end{array}$ & $\begin{array}{l}\text { Reflection on } \\
\text { the phenom- } \\
\text { enon. }\end{array}$ \\
\hline $\begin{array}{c}\text { A experiência } \\
\text { existencial de } \\
\text { mães de crianças } \\
\text { hospitalizadas } \\
\text { em Unidade de } \\
\text { Terapia Intensiva } \\
\text { Pediátrica } \\
\end{array}$ & $\begin{array}{l}\text { Self-knowledge; } \\
\text { reflections; read- } \\
\text { ing of literary } \\
\text { works. }\end{array}$ & $\begin{array}{l}\text { Insertion in study } \\
\text { area; informal } \\
\text { dialogue. }\end{array}$ & $\begin{array}{l}\text { Data collection - } \\
\text { interview using } \\
\text { semistructured } \\
\text { script. }\end{array}$ & $\begin{array}{l}\text { Reading and } \\
\text { study of testimo- } \\
\text { nies; elaboration } \\
\text { of the categories. }\end{array}$ & $\begin{array}{l}\text { Reflection on } \\
\text { the phenom- } \\
\text { enon. }\end{array}$ \\
\hline $\begin{array}{l}\text { O significado } \\
\text { do transplante } \\
\text { de fígado para o } \\
\text { paciente em lista } \\
\text { de espera: abor- } \\
\text { dagem fenom- } \\
\text { enológica }{ }^{16}\end{array}$ & $\begin{array}{c}\text { Self-knowledge; } \\
\text { deepening; reflec- } \\
\text { tions; reading of } \\
\text { phenomenology } \\
\text { books. }\end{array}$ & \begin{tabular}{|c|} 
Three meetings \\
(nursing con- \\
sultation) for \\
integration and \\
data collection: \\
semistructured \\
interview and field \\
diary.
\end{tabular} & $\begin{array}{l}\text { Characterization } \\
\text { of demographic } \\
\text { and clinical data; } \\
\text { analysis of testi- } \\
\text { monies; construc- } \\
\text { tion of categories } \\
\text { and subcategories }\end{array}$ & $\begin{array}{l}\text { The meaning of } \\
\text { the transplan- } \\
\text { tation for the } \\
\text { patients who are } \\
\text { awaiting a liver } \\
\text { as an essential } \\
\text { condition for their } \\
\text { survival. }\end{array}$ & $\begin{array}{l}\text { Not addressed } \\
\text { according to } \\
\text { the authors. }\end{array}$ \\
\hline
\end{tabular}


Lélis ALPA, Pagliuca LMF, Cardoso MVLML

\begin{tabular}{|c|c|c|c|c|c|}
\hline $\begin{array}{c}\text { O processo de } \\
\text { parir assistido } \\
\text { pela enfermeira } \\
\text { obstétrica no con- } \\
\text { texto hospitalar: } \\
\text { significados para } \\
\text { as parturientes }\end{array}$ & $\begin{array}{c}\text { Preparation for } \\
\text { the meeting. }\end{array}$ & $\begin{array}{c}\text { Meetings; partici- } \\
\text { pant observation; } \\
\text { register of testimo- } \\
\text { nies in field diary. }\end{array}$ & $\begin{array}{c}\text { Transcription and } \\
\text { reading of the } \\
\text { material; organi- } \\
\text { zation and group- } \\
\text { ing of themes; } \\
\text { establishment of } \\
\text { central category. }\end{array}$ & $\begin{array}{c}\text { Not addressed } \\
\text { according to the } \\
\text { authors. }\end{array}$ & $\begin{array}{c}\text { Not addressed } \\
\text { according to } \\
\text { the authors. }\end{array}$ \\
\end{tabular}

Most of the studies were guided by the five phases of the Humanistic Theory as methodological support to develop the study. In the first phase, predominantly, knowledge on the study object and the Theory was obtained, concomitantly with moments of reflection and introspection for the authors' self-knowledge. In the second phase, the integration with the subjects took place, followed by data collection through observation, interview and drawings. It is highlighted that informal dialogue was an alternative for previous contact with the participants. The relation among subjects was aimed for, considering that intuitive knowledge is developed without the intent to use analytic reasoning with these subjects, emphasizing the I-YOU relationship.

In the third phase, the data were organized and analyzed, when the authors immersed in the content extracted from the data collection, with a view to scientifically examining the content of the testimonies, establishing the I-IT relationship. The fourth phase involved the interpretation, comparison, classification for synthesis and establishment of the thematic units or categories. In the final phase, based on the participants and the authors' general view, the data were confronted with other related studies and literature sources, resulting in a conception or reflection on the study phenomenon.

\section{DISCUSSION}

A study on the knowledge production about nursing theories published in seven Brazilian nursing journals between 1998 and 2007 found that Paterson and Zderad's Humanistic Nursing Theory was the most used reference framework in the nursing studies. ${ }^{18}$ The number of studies that applied the phases of the theory was not specified though.

In studies published in indexed journals, not included in the sample, as they were not identified in the search process in the databases, but which did apply the phases of the Humanistic Theory, a qualitative design was found, using a population of parents of children with Down Syndrome, mothers of infants in phototherapy and nurses working at a Neonatal Intensive Care Unit (NICU), ${ }^{9,19-20}$ in line with the characteristics of the publications selected for this study.

Concerning the predominance of qualitative studies, the Humanistic Theory follows this approach, respecting its origin in phenomenology, together with the ethnography-based theories. The research traditions referred to provide the dominant structure that theoretically supports the qualitative studies. ${ }^{1}$

In view of the existence of three other studies not included in the sample, ${ }^{9,19-20}$ the choice was made to present them in this discussion, with a view to demonstrating the similarities in the application of the phases, in accordance with the selected studies, besides highlighting differences, specifically in the third, fourth and fifth phases, organized according to the rules of the theory.

\section{Nurse preparation for coming to know}

In this phase, the nurses get prepared, introspective and scientifically, to start investigating the phenomenon. They demonstrate their accessibility and availability for other experiences and perceptions, free themselves from prejudices and judgments and, at the same time, acknowledge their own worldview. This moment involves the preparation of the mind to get to know the clinical or research area, which can be accomplished by reading works from the humanities, reflect on them and compare them with what is known, which is the nursing practice..$^{5-6,8}$

In general, in the selected studies, the authors sought self-knowledge through dialogue, introspection, experiences and literary support related to the research objects, besides the deepening of the literature on the Humanistic Theory. ${ }^{11-17}$ In one of the studies, the readings included books, dissertations and papers, watching movies and participating in congresses. ${ }^{12}$ As perceived, that is the preparation phase for the data collection.

Nurse preparation for coming to know started with introspection, readings, dialogue with the health team at the institution that served as the 
data source, and the collection of documentary data from the patient files, so as to characterize the mothers and infants. ${ }^{20}$ The same happened with the readings about the humanistic theory, focused on in the theme relevant to the research. In addition, further contact with the research scenario and the nurses who participated in the study was sought through daily visits to the service and informal conversations. ${ }^{9}$ Group dynamics were employed, supporting the literature review and clarifying the research problem. ${ }^{19}$

\section{Nurse's intuitive knowledge about the other - I-YOU relationship}

This phase generates particular knowledge, called intuitive, which supposes the I-YOU relationship and also presupposes that it is open to the other's experiences. ${ }^{7}$

The second phase includes the approximation of the subjects and the study scenario, informal conversations, participant and non-participant observation, verbal and non-verbal communication, narrative testimonies, interview, observation of drawings and observations registered through a field diary and recorded testimonies..$^{12-21}$ Hence, this phase took place to get familiar with the scenario and get closer to the participants, followed by the data collection, involving the use of methods commonly applied in qualitative research.

For the sake of greater involvement with the participants' families, dynamics were held as appropriate. ${ }^{19}$ Individual meetings took place for semistructured interviews, followed by the presentation of an "illustrated panel", containing the trajectory of the phototherapy, risks and benefits, besides the nursing care for infants undergoing phototherapy. ${ }^{20} \mathrm{~A}$ meeting with the participating nurses to explain the research objectives and the completion of the questionnaire was included in this phase. ${ }^{9}$

\section{Nurse's scientific knowledge about the other - I-IT relationship}

After experience the presence (I-YOU relationship) in the meeting between the beings, the other is interpreted as an object, establishing the I-IT relationship. ${ }^{18}$ That permitted the insertion of Nursing in this context. It is highlighted that, from a scientific perspective, the nurses analyze the other as an object that can be classified, compared, interpreted, related, named and categorized.
In accordance with four studies, this phase was characterized by the distancing from the object, listening, transcription, moment of reflection, analysis of statements, comparison, interpretation, visualization and classification of ideas and contrasts. ${ }^{11-14,16-17}$ In addition, in line with two publications, ${ }^{16-17}$ the categories could be constructed.

In one of the publications, the authors extended the data collection to the third phase of the theory, ${ }^{15}$ as opposed to the other studies that ended the collection in the second phase. This finding was repeated in another studies, in which the following guiding question was presented to the interviewee: what is it like to live with a person who has Down's syndrome? The observations and answers were registered in a field diary. ${ }^{19}$

The statements were organized in categories, analyzed and interpreted in the light of the theory. In this phase, the goal was to synthetize themes and to interpret the experiences inside the reality experienced with the participating mother. Distancing from the research object was necessary though, in the temporal as well as spatial sense. ${ }^{20}$

Exhaustive and analytic readings of the participants' responses took place and, next, based on the understanding and synthesis of the collected data, the thematic categories emerged, which were interpreted in the light of the premises of the theory, which determined the fourth and fifth phases of phenomenological nursing. ${ }^{9}$

As emphasized, in the two studies mentioned earlier, ${ }^{9,20}$ the authors mixed the third and fourth phases of the Theory to develop the research, evidencing that the sequence was merely didactical, as the phases are not fixed, but dynamic and interconnected. ${ }^{21}$

This phase of the Humanistic Nursing Theory method demonstrates its phenomenological aspect focused on the analysis of a human situation from the perspective of the singular experience of the human being, in all of the different dimensions involved in the space and time experienced. ${ }^{22}$

\section{Nurse's supplementary synthesis about the realities she/he knows - expanded view of the phenomenon}

In this phase, the nurse compares and synthetizes the multiple known realities. This synthesis, however, is more than an aggregate, as it permits the mutual representation and signals the existing relation between the realities. ${ }^{5}$ Hence, in comparing the realities found, the nurse should synthetize 
them in a complementary manner, constituting an expanded view of the study phenomenon.

In five papers, ${ }^{11-14}$ the categories were presented as they were evidenced in the testimonies on the same theme and the literature on the topic was discussed. The synthesis of what the transplantation means to patients, however, was presented in the fourth phase, ${ }^{16}$ which diverged from the other publications.

The difference also found in this study is highlighted, in which the transcription of the statements, followed by the typing and reading, were done in the fourth phase..$^{19}$ In one of the studies, on the other hand, the authors aimed to analyze the data based on the scientific and subjective knowledge, followed by the comparison, contract and synthesis of the realities the mothers of the infants undergoing phototherapy experienced, from an expanded perspective, through the thematic categories. ${ }^{20}$

\section{Nurse inner succession from many to a paradoxal one}

In a struggle with the community of multiple situations, the nurses reach a conception that is important for the majority or for all. The specific ideas of each situation lead to a unit or a set. In this phase, the nurses reflect based on the fusion of intuitive and scientific knowledge, in a general meaning for the study phenomenon, with a view to its consideration in a unified manner, constituting a paradox. ${ }^{5}$

The nurses' understanding of the phenomenon goes beyond their earlier conceptions and the new knowledge gained, as it involves the understanding of ancient and new truths, reflecting the community of ideas of most or all people. This community, among the multiple realities, can be established through a reflection, a conception or even a concept of the phenomenon.

The nurses' role is highlighted, who unify the known ideas and present a synthesis of what was learned on the study phenomenon, as it could be observed through the reflections in the selected studies. ${ }^{11-18}$

In addition, the conception of the study phenomenon can be represented as follows "being a mother of an infant undergoing phototherapy comes with fear and concern out of lack of knowledge on the therapeutics itself". 11:612 The mothers expressed that, sometimes, they felt stressed, tired, trying to administer the conflicts the changes in their daily life had caused. On the other hand, they were looking for coping mechanisms, which were their faith and hope in God. ${ }^{12}$ On another occasion, subjects perceived the importance of distancing the aggressor from contact with the children, which reduced the exposure to revictimization and enhanced the victims' feeling of protection. ${ }^{13}$

Researchers reflected that minors living at the support house for children with HIV/aids need the other in order to believe that they are loved and to feel safe in their environment. This experience of safety probably makes them perceive the space lived as a good place, of games, excursions, receiving care, happy and sad moments, even if they are not in contact with their family members. ${ }^{14}$ The fifth phase is permeated by the genitors' feeling, involving solitude, despair and fear in view of the disease and the child's hospitalization, relating them to the disease severity itself or even to the hostile environment, associated with suffering and death. ${ }^{15}$

The other three studies contained general reflections on the phenomenon, as shown in some excerpts from each research. Hence, the study is cited in which the parents played their role, giving special attention to the child, with regard to education as well as the delivery of love, kindness, gestures of fraternity, in short, guaranteeing a good family base, in the full sense of permanently seeking what is best for their child. ${ }^{20}$

In part of the test, discussing the method, the object of reading and discussion, the authors commented that that was the moment when, after knowing the multiple existing realities, they enhanced their worldview and reached relevant considerations on the experiences of the mothers whose infants were under phototherapy, aware of the importance of effective communication by the health team, so that these mothers could be-better in their experience of the infant in phototherapy. ${ }^{20}$

The meaning of taking care of infants in painful situations revealed that the participating nurses indicated personal responsibilities and preparation which, in turn, should involve attitudes that demonstrate love, kindness, respect, responsibility to provide nursing care. ${ }^{9}$

\section{CONCLUSION}

The application of the phases of the Humanistic Theory in nursing research was evidenced, especially in the pediatric and neonatal contexts. The research reports originated in Brazil, showing 
the Brazilian nurses' acceptance of this theory. All experiments adopted the qualitative research method, in line with the theoretical proposal.

In the critical analysis, this study provided evidence on the applicability of the Humanistic Theory in nursing research and that the phases are applicable as methodological support, as the seven articles presented at least three of the five phases in their development. As verified, there is no standard for the application of the phases, although the studies showed similar ways of conducting each phase of the theory. The first phase was pictured as a moment of personal and professional preparation, before the data collection, in which the deepening of the phenomenon and the understanding of the theory were essential to proceed with the research. As a rule, the second phase was developed through closer contact with the participants and the place of study, followed by the data collection, by means of observation and interviews.

Although the third phase was used in two studies for the data collection, it predominantly served to start the data analysis, involving the distancing of the subjects and the researchers' immersion in the reading of the testimonies. The fourth phase also consisted in an analysis phase, aimed at elaborating a synthesis of the content of the testimonies and of the constitution of the categories. In the fifth phase, reflections on the study phenomenon prevailed, generally presented in the final considerations of each research. The authors reflected on the final knowledge of the research object, supported by an expanded view, including the experiences with the phenomenon, strengthening the results found.

It is believed that the predominance of Brazilian studies limited the analysis of the application of the theory's phases to the reality of nursing research in the country. The researchers hope that the study results can further the understanding about the applicability of the Humanistic Theory in research.

\section{REFERENCES}

1. Polit DF, Beck CT. Fundamentos de pesquisa em enfermagem: avaliação de evidências para a prática da enfermagem. Porto Alegre (RS): Artmed; 2011.

2. Meleis AI. Theoretical nursing: development and progress. Philadelphia (US): Wolters Kluwer Health/Lippincott Williams \& Wilkins; 2012.

3. Kleiman S. Human centered nursing: the foundation of quality care. Philadelphia (US): F. A. Davis Company; 2009.
4. Chinn PL, Kramer MK. Integrated theory and knowledge development in nursing. St. Louis (US): Mosby; 2011.

5. Paterson JG, Zderad LT. Enfermeria humanistic. México: Limusa; 1979.

6. Paterson JG, Zderad LT. Humanistic nursing. New York (US): National League for Nursing; 1988.

7. Campos ACS, Cardoso MVLML. Enfermagem humanística: ênfase na comunicação com mães de neonatos sob fototerapia. Petrópolis (RJ): EPUB; 2008.

8. Praeger SG, Paterson JE, Zderad LT. In: George JB, organizador. Teorias de enfermagem: os fundamentos para a prática profissional. $4^{\mathrm{a}} \mathrm{ed}$. Porto Alegre (RS): Artes Médicas; 2000. p.241-51.

9. Lélis ALPA, Farias LM, Cipriano MAB, Cardoso MVLML, Galvão MTG, Caetano JA. Cuidado humanístico e percepções de enfermagem frente à dor do recém-nascido. Esc Anna Nery. 2011 OutDez; 15(4):694-700.

10. Buber M. Eu e tu. Tradução de Newton Aquiles Von Zuben. $2^{\text {a }}$ ed. São Paulo (SP): Moraes; 1974.

11. Campos ACS, Cardoso MVLML. O recém-nascido sob fototerapia: a percepção da mãe. Rev Latino-Am Enferm. 2004 Jul-Ago; 12(4):606-13.

12. Oliveira NFS, Costa SFG, Nóbrega MML. Diálogo vivido entre enfermeira e mães de crianças com câncer. Rev Eletr Enferm [online]. 2006. [acesso 2012 Jan 11]; 8(1):99-107. Disponível em: http://www. revistas.ufg.br/index.php/fen/article/view/937

13. Silva LMP, Galvão MTG, Araújo TL, Cardoso MVLML. Taking care of children's family in abuse situation considering the humanistic theory. Online Braz J Nurs [online]. 2007 [cited 2012 Jan 11]; 6(1): Available from: http://www.objnursing.uff.br/ index.php/nursing/article/view article/715/162

14. Medeiros HMF, Motta MGC. Existir da criança com aids em casa de apoio: compreensões à luz da enfermagem humanística. Rev Gaúcha Enferm. 2008 Set; 29(3):400-7.

15. Morais GSN, Costa SFG. A experiência existencial de mães de crianças hospitalizadas em Unidade de Terapia Intensiva Pediátrica. Rev Esc Enferm USP. 2009 Set; 43(3):639-46.

16. Aguiar MIS, Braga VAB. O significado do transplante de fígado para o paciente em lista de espera: abordagem fenomenológica. Rev Cuba Enferm. 2012 Set-Dez; 28(4):485-94.

17. Caus ECM, Santos EKA, Nassif AA, Monticelli M. O processo de parir assistido pela enfermeira obstétrica no contexto hospitalar: significados para as parturientes. Esc Anna Nery. 2012 Jan-Mar; 16(1):34-40.

18. Schaurich D, Crossetti MGO. Produção do conhecimento sobre teorias de enfermagem. Esc Anna Nery. 2010 Jan-Mar; 14(1):182-8. 
19. Ramos AF, Caetano JÁ, Soares E, Rolim KMC. A convivência da família com o portador de Síndrome de Down à luz da Teoria Humanística. Rev Bras Enferm. 2006 Mai-Jun; 59(3):262-8.

20. Campos ACS, Cardoso MVLML. Enfermagem e o cuidado humanístico: proposta de intervenção para a mãe do neonato sob fototerapia. Cienc Enferm. 2006; XII(1):73-81.
21. Campos ACS. Comunicação com mães de neonatos sob fototerapia: pressupostos humanísticos [tese]. Fortaleza (CE): Universidade Federal do Ceará. Programa de Pós-Graduação em Enfermagem; 2005.

22. Paula CC, Crossetti MGO. O modo de cuidar no encontro com o ser-criança que convive com aids: o experienciar da finitude e a ética. Texto Contexto Enferm. 2005 Abr-Jun; 14(2):193-201. 